\title{
Research on the Digitization Construction of Personnel Files of University Cadres
}

\author{
Xinming Lu
}

Baoshan University, Yunnan, China, 678000

Keywords: colleges and universities; personnel files of cadres; digital construction

\begin{abstract}
The digitalization of archives is to transform the file information of various traditional media such as paper, photographs, audio and video, and film, into digital information through computer technology, and complete the basic construction of file informationization. This information is connected and provided through the use of high-speed broadband communications network facilities to enable true resource sharing. The digitization of personnel files in colleges and universities is a long-term strategic task. In the course of development, a variety of new problems will surely be encountered. How to ensure the smooth construction of digital archives in colleges and universities in the aspects of management system and management methods for personnel files in colleges and universities, is an important topic in front of the archives workers in colleges and universities ${ }^{[1]}$.
\end{abstract}

\section{Introduction}

With the rapid development of higher education and the ever-increasing scale, the number of teachers in universities has been constantly expanding and the flow of talents has become more frequent. The existing management mode for personnel files in colleges and universities has been unable to meet the needs of the development of the situation and strengthen the personnel files of college cadres. Management and continuous innovation have become problems that universities must solve. The innovation of cadre and personnel file management methods and management methods is an important part of the institutionalization, standardization, and informationization of cadre personnel files, and it is also the need of the times for the development of social progress.

\section{Status Quo of University Personnel File Management}

The cadre and personnel files work is an important part of organizing personnel work and provides an important basis for using cadres and selecting talents. In recent years, cadres and personnel files in colleges and universities have made great progress in the management team, system construction, information construction, etc. But it is undeniable that there are still more common and cannot be ignored.

\subsection{Weak file awareness and low level of professionalism}

The leaders of various colleges and universities have weak awareness of files in varying degrees, and they do not pay enough attention to the management of cadres' personnel files. They do not invest enough in the personnel, finances, and materials needed for cadres' personnel files, and they lack training and training of full-time file personnel ${ }^{[2]}$. The management team is too old, there are relatively few archival professionals, and there is insufficient equipment. In addition, the lack of theoretical training and basic skills training for archivists in the universities makes it difficult to form a contingent of qualified archivists with a reasonable, scientific, and efficient file management system. The development of cadre personnel file management work. 


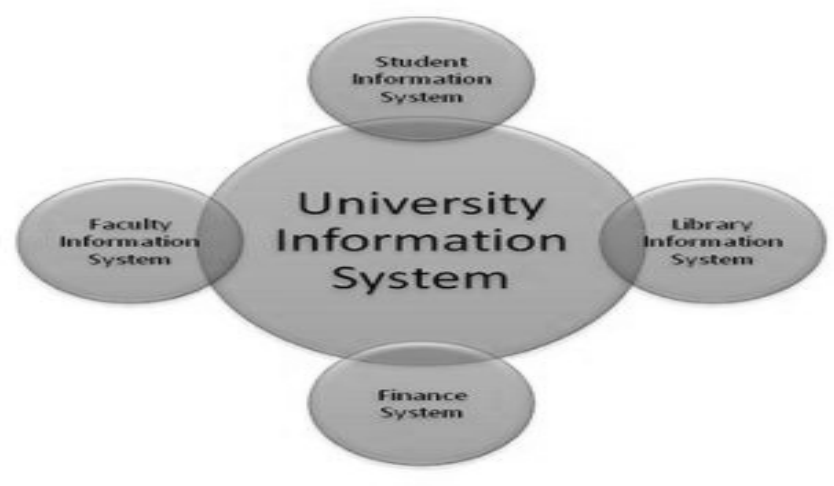

Fig.1 Digital Construction Contacts for College Personnel Files in Colleges

\subsection{The management tools are backward, the concept is old, and the level of information is low}

The management of personnel files in colleges and universities has always followed the traditional manual-based management model. The provision and use of files is based on paper-based physical files. The work efficiency is low, and the procedures for checking and borrowing are tedious and the service methods are backward. The widespread use of heavy-handed awareness led to the closed operation of archives among organizations, personnel, and file management personnel. Although most colleges and universities use computers to manage cadre personnel files, they have only produced archive indexing tools and archives catalog databases, and the degree of informationization and digitization of cadre personnel files is relatively low ${ }^{[3]}$.

\subsection{The lack of implementation of the management system should be implemented}

At present, many universities and colleges have deficiencies in the management system of cadre personnel files. Some of them do not have corresponding job responsibilities, lack systemic and scientific rules and regulations, and lag behind in management systems. The collection channels for personnel files of cadres are relatively narrow. File management personnel actively collect poor awareness, so that "the materials of the members of the National People's Congress, the CPPCC, etc., and the materials reflecting the academic research level of individuals" are not well collected and archived. The archival materials are often neglected in the identification examination, which results in distortion of some archival materials and impairs the authenticity of the archives. The obvious lack of archival materials but lack of completeness in the archives impairs the integrity of the archives. The emergence of the above-mentioned phenomena has a direct bearing on the incomprehensible implementation of the cadre personnel file management system and the lack of a proper post responsibility system.

\section{College Cadre Personnel File Management Innovation Initiatives}

\subsection{Strengthening the Construction of the Archives Management Team and Training Compound Talents}

The application of computer technology and network technology has brought new and higher requirements to file management and file management. The quality of file management work depends directly on the quality of archivists. Therefore, as a cadre personnel file management personnel in the new era, we must emancipate the mind, advance with the times, and strive to improve our overall quality and adapt to the development and requirements of the personnel archives undertaking in the new era.

From the current point of view of the management of personnel files in colleges and universities, the vast majority of file management staff currently on the job do not have professional knowledge of the archives. 


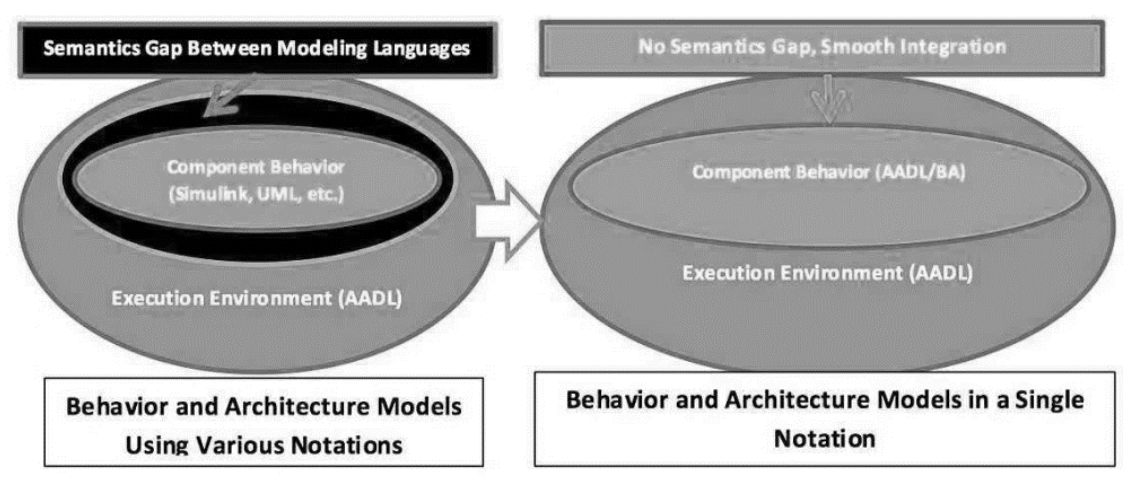

Fig.2 Trends in digital construction of archives and links with modern education

\subsection{Innovate Management Mode and Improve Informationization}

Accelerate the informationization of cadre personnel file management, use modern information technology, assist scientific, rational and efficient file management, and improve the level and efficiency of file management. Traditional manual-based management methods have low work efficiency, large workload, and high labor intensity, and these problems can be well solved through information technology. The use of computers, networks, and other technologies to establish databases of cadre personnel file information is the main method for promoting the construction of archives information.

\subsection{Innovative file management rules and regulations to achieve scientific management}

Establishing and perfecting various file management rules and regulations is an important symbol for the scientific and standardized management of cadres' personnel files. Although universities and colleges have achieved some practical results in the construction of the cadre personnel file system, there are still problems such as the imperfect system and inadequate implementation of the system, which have affected the management of personnel files in colleges and universities [3].

\section{College Personnel File Information Management Countermeasures and Suggestions}

\subsection{Fully understand the importance of personnel file information}

It is necessary to fully understand the importance of personnel file informationization. It is necessary to actively and steadily promote the process of informationization of personnel files under the guidance of national policies. We will continue to increase financial and human resources and strengthen infrastructure construction. Provide the necessary material basis. To actively take measures. The indicator uses all the data of the region, so the amount of information contained is adequate. The commonly used weighted coefficient of variation is also called the Wilson coefficient [2]. Its formula is:

$$
V u=\frac{1}{x^{\prime}} \times \sqrt{\sum_{i=1}^{\mathrm{n}} \frac{\left(x_{i}-x\right)^{2} p_{\mathrm{i}}}{p}}
$$

The per capita in the i region, the per capita in the background region, the population in the $\mathrm{i}$ region and the total population in the background region. Increase infrastructure construction efforts. The construction of personnel file informatization is regarded as an important part of personnel work in colleges and universities.

\subsection{Establishing a sound system of rules and regulations and business norms}

The construction of personnel files informatization is a new requirement and task for the management of personnel files in colleges and universities in the new era. Therefore, it is 
impossible to copy the system of the traditional manual management stage, and the corresponding workflow and rules and regulations must be formulated in light of the progress of the informatization construction of each school and the actual situation of personnel file informatization management. Make file management work rules. Promote the management of personnel files to institutionalized and standardized development.

\section{Summary}

Improving the Professional Quality of Records Management Personnel One of the key factors in the construction of personnel file informationization is to build a highly qualified personnel for file information management. In the personnel file construction process. We must keep abreast of the times in consciousness. Constantly updated service concept. Good at using modern management equipment to innovate service. Improve service efficiency. Adapt to new service needs. We must also have the habit of constantly learning new knowledge, new technologies, and new ideas. In order to be able to work in the standardization, standardization, high efficiency and high quality of information management jobs.

\section{References}

[1] Ji R. Preliminary Study on the Accuracy and Management of the Cadres' Personnel Files[J]. Journal of Baotou Vocational \& Technical College, 2009.

[2] Cheng L. Information Managements of University Cadre Personnel Files[J]. Value Engineering, 2011.

[3] Huang Y J. Thinking of personnel files for cadres based on human resources management[J]. Journal of Pingdingshan Institute of Technology, 2009. 